taken during the year, but the Corporation's major preoccupation during the period was in respect of the hovercraft, Dracone, and fuel-cell inventions, which represented $£ 475,000$ of its development expenditure. The report records the decision of three British firms to establish with the Corporation a new company for fuel-cell research, development and manufacture. There will be no further work on the acetylene project. During the year the Joint Development Committee with the Department of Scientific and Industrial Research considered and advised on 17 proposals for research and development, and also on investigations undertaken by the Department and the Corporation of the technical needs of several industries. During the latter part of the year the Corporation started to organize a survey of the solidstate sciences with the view of formulating proposals for research and development, particularly in relation to the mechanical properties of solids.

At the end of the year the Corporation had in its portfolio the rights in 3,400 United Kingdom and overseas patents and patent applications, derived chiefly from publicly supported research in Government research establishments, the Research Councils and the universities, as well as $\mathbf{4 9 5}$ licence agreements with firms in industry in the United Kingdom and 48 overseas agreements, chiefly with United States firms. Of 973 inventions communicated during the year 312 were from Government departments and research councils, 115 from universities, 31 from
Commonwealth official organizations, 8 from industrial research associations and 7 from charitable organizations. Private firms and individuals in the United Kingdom contributed 466, in the Commonwealth 12 and elsewhere overseas, 20 . Of the 154 patent rights assigned 99 were from Government departments and research councils, 47 from universities and 5 from private firms and individuals in the United Kingdom. At the end of the year the Corporation held 653 United Kingdom and 1,115 overseas granted patents and 369 United Kingdom and 1,252 overseas patent applications; for its subsidiary development corporation the corresponding figures are 4 and 56 patents, and 57 and 351 patent applications, respectively. At the end of the year 30 potential development projects were being assessed and some 500 communications were again received from private sources during the year, and it is to be noted that besides C. S. Corkerell's hovercraft and F. T. Bacon's fuel-cell, H. D. Fanshawe's automatic drilling rig, F. G. de B. Perry's infinitely variable speed gear, T.M. Lewis's continuous leather-processing equipment and P. Eisler's printed electrical circuits have been forwarded in this way. The new projects under development include, besides those already mentioned, those for anti-histamine substances for blood, a fat-mobilizing factor, a photo-typesetting machine, a smooth muscle stimulant, a vaccine for treating trachoma, and ultrasonic diagnosis equip. ment.

\title{
RECENT VETERINARY PUBLICATIONS
}

A

FEATURE of scientific literature during recent years has been the increasing variety and range of publications devoted to veterinary science and also the high quality of the research work which these publications record.

Animal Production, for example, which is the journal of the British Seciety of Animal Production, devotes itself, as its title indicates, to all aspects of the rearing and maintenance of all kinds of farm stock. So far, three volumes (Oliver and Boyd, Edinburgh. Annual subscription $45 s$. or 7.50 dollars; single Nos. 17s. $6 d$. or 2.75 dollars) have been published, and the journal has established itself as one which all who are concerned with this subject must have.

Animal Breeding Abstracts, which is prepared by the Commonwealth Bureau of Animal Breeding and Genetics, Edinburgh, has a wider scope. It is published quarterly by the Commonwealth Agricultural Bureaux, Farnham Royal, England (annual subscription, 90s.). The abstracts in it are compiled from world literature and it publishes review articles on selected subjects. Up to December 1961, twenty-nine volumes have bcen issued.

For ontomologists the Bulletin Singalétique d'Entomologie médicale et vétérinaire (Office de la Recherche Scientifique et Technique Outre-Mer, 24 rue Bayard, Paris) publishes the titles only of a wide variety of papers on this subject.

Much wider or, indeed, as some would put it, monumental in its scope, is the Animal Health Yearbook, published jointly each year by the Food and Agricultural Organization and the Office Internationale des Epizootie from their headquarters in the viale delle Terme di Caracalla, Rome. It is printed in English, French and Spanish. The latest (1961) issue of this astonishing mine of information about the causes, incidence and control of diseases of animals all over the world contains information available up to December 1960.

From the Food and Agriculture Organization also comes the very useful working document entitled $A$ Laboratory Handbook of Veterinary Diagnostic Procedures compiled by A. J. Stevens (Animal Health Branch Monograph No. 3. Pp. ii + 70. Rome, 1961). This typewritten document contrives to give in 70 pages details of all the important diagnostic methods used in veterinary practice, and veterinarians will find it a valuable addition to the practical books in their surgeries.

For poultrymen generally, the publication issued by the Ministry of Agriculture, Fisheries and Food entitled Poultry Nutrition (Bulletin No. 174. Pp. $\mathrm{v}+90$. London: H.M.S.O., 1960. 5s. net), by Dr. W. Bolton, of the Agricultural Research Council's Poultry Research Centre, Edinburgh, gives a valuable account of the essentials of this subject. It discusses the various nutrients in poultry foods, the processes of digestion and metabolism, the importance of vitamins and the various cereals, vegetable and animals protein foods, green food and food additives to be used, and also deleterious substances, the formulation of poultry diets, the efficiency of food utilization and recommended formulæ for poultry mashes, and also contains a chapter on the value of poultry products in human diets.

Finally, laboratory workers especially will be interested in Volume 10 of the Collected Papers Series published by the Laboratory Animals Centre (Medical 
Research Council Laboratories, Woodmansterne Road, Carshalton, Surrey. 12s. 6d.). This volume is entitled Hazards of the Animal House, and in it a number of experts discuss these hazards in general and those associated with large-scale experiments with monkeys, and those met with when dogs, cats, farm animals and birds are handled or when poliovirus is being used. Other papers discuss the precautions needed against tuberculous infection of the animal house and what virus and bacterial infections may be acquired from rats and mice. This publication is, of course, only one of others issued by the Laboratory Animals Centre. Among them is the typewritten
Bulletin issued every March and September by the International Committee on Laboratory Animals. The issue dated September 1961 continues the useful information given by former issues of this publication about the breeding, maintenance and transport of laboratory animals and other problems associated with their production and care. Appended to this issue is a list, 100 pages long, of the literature on laboratory animals of all kinds. This useful bibliography has been compiled from publications in various countries by M. A. Sabourdy and C. M. Taisne, of the Centre de Selection des Animaux de Laboratoire, Gif-sur-Yvette, France. G. LAPAGE

\section{INDIAN STUDENTS IN BRITAIN}

INDIAN students constitute the largest single body of overseas students at British universities. During the session 1960-61 the total number of Indian university students in Britain was 1,513 .

Although there have been previous studies of overseas students, there has been no investigation into the experiences in Britain of Indian students. A survey, described in a recent issue of Planning*, was carriod out to determine what impact has been made on the lives of a sample of Indian students who have been living in Britain for some time. The survey was carried out during the years 1959-61. Information was collected by means of questionnaires and interviews from four hundred students attending the Universities of London (200), Oxford and Cambridge (100) and Manchester and Leeds (100). The survey was confined to men as the number of Indian women students in Britain is very small.

The investigation showed that most of the students gain a new awareness and new perspectives in their genoral outlook on life. They not only meet British people, but they also meet people from various other parts of the world-Europe, Africa, America, and also people from different regions of India. From a distance, they can see India as a single nation with an identity of its own, not only politically but also culturally. They are made conscious of the backwardness and poverty that exists in their own country by contrasting it with the general higher standard of living of Western peoples, and they develop an admiration for the science, technology and organization of the West. They also develop greater admiration for some Indian values and for the Indian way of life, even though they become more critical of illiberal social practices in their country.

In the survey 88 per cent of the Indian students agree that there is no objection to borrowing science and technology from the West, but think that India should adhere to its own values: only 6 per cent disagree. Indian students want their society to change, not only economically but also socially, and they draw their inspiration partly from the Western liberal humanitarian principles of social justice and individual dignity and freedom, and partly from their own ancient traditions of idealism and spirituality. These traditions derive on one hand from those of the Upanishads and the Vedantta, with their intellectual approach, and, on the other, from those of the deeply humane saints of the Bhakti

* Planning, Vol. 27, No. 456 (13 November, 1961): Indian University Students in Britain. Pp. 281-816. (London: Political and Economic Planning, 1961.) $4 \mathrm{~s}$.
Movement, such as Kabir and Ramkrishna, with their emotional appeal.

Coming to Britain is not an isolated event, a closed and cut-off period, in the lives of the Indian students. It is fitted into and rounded off the pattern of their lives. Their experiences in Britain are influenced by their conditions back at home and by their future aspirations.

In general, middle-class Indian students have more to win and more to lose than upper-class students in the attempt to gain a foreign degree. Typically, the middle-class students are the first generation to receive an overseas education in their families, or perhaps even in their local communities. For them the experience is more magical and more exciting. Their foreign degree, as they see it, is going to bring them greater social status and prestige and raise the position of themselves and their families in the Indian social hierarchy.

Because they are financially handicapped, a delay of a few months puts a great strain on them. A few days lost through illness; a few extra months spent making up for inadequate academic preparation; a few more months over their 'schedule', inevitable because of the natural problems involved in research; a few months spent on improving work of a poor standard, poor perhaps because it is done hastily and under strain; the unexpected failure of their arranged sources of finance; the time and energy spent in some uninteresting part-time job; or bad news from horne -all these greatly disorganize and worry them.

The upper-class students have comparatively little at stake. Their families have been well established in Indian society for generations. Education overseas has become a matter of routine and is almost taken for granted. It is not an object of special ambition. Their parents and grandparents have also been educated in Britain. They add nothing of significance to the social positions of their families by adding foreign degrees, except that it is rather odd to move in a community full of 'English-returned' persons without this cachet. They are financially well-off and the expenses of their education in Britain does not put any strain on their families. A delay of a few months or a year in completing their studies does not make much difference.

Within this overall group of students there is a variety of problems. By bringing the findings of the survey before a wider public, Political and Economic Planning hopes to contribute towards a greater understanding of the difficulties confronting Indian students in Britain and also to provide a basis for administrative action. Overseas students should have 